Arq. Bras. Med. Vet. Zootec., v.60, n.2, p.492-495, 2008

\title{
Communication
}

[Comunicação]

\section{Hematological profile of healthy Pantaneiro horses}

[Valores do hemograma em cavalos sadios da raça Pantaneiro]

\author{
C.R. Ribeiro ${ }^{1}$, J.J. Fagliari ${ }^{1}$, P.D. Galera $^{2}$, A.R. Oliveira ${ }^{3}$
}

${ }^{1}$ Faculdade de Ciências Agrárias e Veterinárias - UNESP - Jaboticabal, SP

${ }^{2}$ Faculdade de Agronomia e Medicina Veterinária - UnB - Brasília, DF

${ }^{3}$ Universidade de Cuiabá - Cuiabá, MT

Pantaneiro horse is small in size (averaging= $137.7 \mathrm{~cm})$, docile, and rustic, having characteristics developed over the course of four centuries of natural selection in the Pantanal region of Mato Grosso, Brazil (Beck, 1985; Santos et al., 1995; Miserani et al., 2002). They are descendents of Andalucian and Lusitano horses of the Iberian peninsula (Cothran et al., 1998). The characteristics of Pantaneiro horses differ from those of other breeds due the need to adapt to the Pantanal environment. During its evolution, the Pantaneiro horse lost its aesthetic beauty and took advantage of zootechnical characteristics targeted for function. It developed a straight and tall frame, similar to that of a mule, conferring a tolerance to immersion in water for prolonged periods. Historically, this breed is used for working (e.g., cattle handling); however, currently, it is also being used for sporting due to notable physical capacity (Beck, 1985; Santos et al., 1995).

There is a vast literature with regard to hematological normal values for horses. Most of these are adult and athletic and whose physical conditioning and nutritional and hygienic management differ from the majority of the equine population, mainly with respect to the Pantaneiro breed (Lumsden et al., 1980; Tyler et al., 1987; Rose and Rodgson, 1994; Noronha et al., 2000; Feldman et al., 2000; Cunha et al., 2008).
Riding long distances, a type of endurance test that submits the animal to exercise of low intensity and long duration, has become a popular form of equestrian activity in the Pantanal region of Mato Grosso, Brazil (Ribeiro et al., 2004). Therefore, the knowledge of reference values for the hematological profile of healthy Pantaneiro breed horses, both males and females, of different ages, has become of extreme importance.

This study included 187 Pantaneiro horses bred in the Pantanal region of Mato Grosso, Brazil. They were clinically healthy and negative for infectious equine anemia after examination. The horses were reared in ranches and farms that furnished satisfactory nutritional and sanitary conditions. Feed management involved the use of native pastures consisting of Axonopus purpusii, Reimarochloa brasiliensis, Hymenachne amplexicaulis, Setaria geniculata, and Pontederia cordata and cultivated pastures of mainly Panicum maximum var. Tanzânia, Andropogon gayanus kunth, and Hyparrhenia rufa with water ad libitum. Those animals were kept in large-area pastures and were periodically submitted to sanitary management (e.g., worming, vaccination, and blood sampled for serological tests for infectious equine anemia) or kept in paddocks close to the center of the property, especially the pregnant mares, foals, stallions, and castrated males that were used in daily work and sport activities.

Recebido em 28 de agosto de 2007

Aceito em 25 de fevereiro de 2008

Endereço para correspondência (corresponding address)

SQN 206 Bl. F, apt. 205 - 70844-060 - Brasília, DF.

E-mail: cassio.veterinario@gmail.com 
The horses were distributed into six experimental groups as follows: group I - 30 animals, males and females, aged up to eight months; group II 30 males aged from nine to 24 months; group III - 28 females aged from nine to 24 months; group IV - 36 pregnant females; group V - 33 noncastrated adult males (stallions); group VI - 30 castrated adult males (geldings).

A single $10 \mathrm{ml}$ blood sample was collected from the animals after a routine physical examination to confirm their healthy state (Speirs, 1997). They were obtained from the jugular vein, using tubes with EDTA ${ }^{1}$. A differential cell count was performed on slides of blood smears after staining - Diff-Quick ${ }^{\circledR}$ (Feldman et al., 2000).

Erythrocyte and leukocyte counts were carried out using a Neubauer chamber (SPEIRS, 1997). Hemoglobin concentration was determined by the cyanomethemoglobin method, with spectrophotometric readings at $540 \mathrm{~nm}^{2}$. Packed cell volume was determined by the microhematocrit method. RBC indexes, mean corpuscular volume (MCV), and mean corpuscular hemoglobin concentration (MCHC) were calculated according to standard formulas (Feldman et al., 2000).

The obtained values were submitted to statistical analysis using the SAS program (User's..., 1985), which determined the means, standard deviations, coefficients of variation, and extreme limits and performed an analysis of variance. Tukey's test was employed at a level of significance of $\mathrm{P} \leq 0.05$ to compare the differences between the means.

Table 1 presents the results of the red blood cell count, packed cell volume, hemoglobin concentration, the $\mathrm{RBC}$ indices $\mathrm{MCV}$ and $\mathrm{MCHC}$, leukocyte count, numbers of segmented neutrophils, band neutrophils, lymphocytes, eosinophils, monocytes and basophils. Because of the wide variation in the obtained values for eosinophils, monocytes, and basophils, the means and minimum and maximum values are listed in Table 1.

Table 1. Means standard deviations of hematological profile of Pantaneiro breed horses according to experimental group

\begin{tabular}{|c|c|c|c|c|c|c|}
\hline Parameter & Foals to 8 months & $\begin{array}{l}\text { Foals } 9 \text { to } 24 \\
\text { months }\end{array}$ & $\begin{array}{c}\text { Fillies } 9 \text { to } 24 \\
\text { months }\end{array}$ & Pregnant mares & Stallions & Geldings \\
\hline $\mathrm{RBC} / \mu \mathrm{l}\left(\mathrm{x} 10^{6}\right)$ & $7,82 \pm 1,53 b$ & $8,63 \pm 1,37 a$ & $8,87 \pm 2,32 \mathrm{a}$ & $7,09 \pm 2,06 \mathrm{bc}$ & $7,94 \pm 1,58 \mathrm{ab}$ & $6,20 \pm 1,20 \mathrm{c}$ \\
\hline PCV (\%) & $35,17 \pm 4,26 \mathrm{ab}$ & $36,56 \pm 4,04 a b$ & $37,00 \pm 2,76 \mathrm{a}$ & $35,11 \pm 3,94 \mathrm{bc}$ & $35,93 \pm 4,44 \mathrm{ab}$ & $32,03 \pm 4,02 \mathrm{c}$ \\
\hline $\mathrm{Hb}(\mathrm{g} / \mathrm{dl})$ & $11,50 \pm 1,03 b$ & $12,54 \pm 2,80 \mathrm{ab}$ & $12,66 \pm 1,38 \mathrm{a}$ & $11,64 \pm 2,20 \mathrm{~b}$ & $12,75 \pm 1,55 \mathrm{a}$ & $11,93 \pm 1,17 \mathrm{~b}$ \\
\hline MCV (fl) & $42,53 \pm 6,34 \mathrm{c}$ & $42,07 \pm 6,15 \mathrm{c}$ & $44,67 \pm 13,12 \mathrm{c}$ & $55,90 \pm 13,48 \mathrm{a}$ & $48,31 \pm 10,66 b$ & $52,97 \pm 8,79 \mathrm{ab}$ \\
\hline MCHC (g/dl) & $32,41 \pm 4,87 \mathrm{c}$ & $34,01 \pm 2,60 \mathrm{c}$ & $34,64 \pm 1,13 b$ & $34,08 \pm 7,90 \mathrm{bc}$ & $35,15 \pm 3,89 \mathrm{ab}$ & $37,66 \pm 4,88 \mathrm{a}$ \\
\hline $\mathrm{WBC} / \mu \mathrm{l}\left(\mathrm{x} 10^{3}\right)$ & $15,54 \pm 4,71 \mathrm{ab}$ & $14,19 \pm 3,37 \mathrm{bc}$ & $16,97 \pm 2,80 \mathrm{a}$ & $11,02 \pm 3,18 \mathrm{~d}$ & $12,15 \pm 4,22 \mathrm{~cd}$ & $11,37 \pm 3,78 d$ \\
\hline Segs $/ \mu 1\left(\mathrm{x} 10^{3}\right)$ & $7,25 \pm 2,71 \mathrm{a}$ & $5,48 \pm 1,89 b$ & $7,54 \pm 1,52 \mathrm{a}$ & $4,89 \pm 1,77 b$ & $5,65 \pm 1,86 b$ & $5,18 \pm 1,93 \mathrm{~b}$ \\
\hline Bands $/ \mu 1\left(\times 10^{3}\right)$ & $0,24 \pm 0,26 \mathrm{a}$ & $0,12 \pm 0,17 \mathrm{ab}$ & $0,09 \pm 0,15 b c$ & $0,04 \pm 0,08 \mathrm{c}$ & $0,14 \pm 0,23 \mathrm{ab}$ & $0,10 \pm 0,15 b$ \\
\hline Lymphocytes $/ \mu 1\left(\mathrm{x} 10^{3}\right)$ & $7,03 \pm 2,60 \mathrm{~b}$ & $7,18 \pm 2,80 \mathrm{ab}$ & $8,61 \pm 2,04 a$ & $5,40 \pm 2,18 \mathrm{c}$ & $5,69 \pm 2,77 \mathrm{bc}$ & $5,19 \pm 2,04 \mathrm{c}$ \\
\hline Eosinophils / $\mu 1^{*}$ & $717(0-2.160) \mathrm{a}$ & $323(0-1.311) \mathrm{a}$ & $434(0-870) b c d$ & $480(0-1.202) b c$ & $375(0-1.607) \mathrm{cd}$ & $602(0-1.603) a b$ \\
\hline Monocytes $/ \mu 1^{*}$ & $284(0-1026) \mathrm{a}$ & $261(0-1.311) \mathrm{a}$ & $253(0-654) \mathrm{a}$ & $235(0-875) \mathrm{a}$ & $259(0-689) \mathrm{a}$ & $280(0-918) a$ \\
\hline Basophils / $\mu 1^{*}$ & $11(0-204) \mathrm{a}$ & $6(0-176) \mathrm{a}$ & $0(0-0) \mathrm{a}$ & $8(0-145) \mathrm{a}$ & $9(0-175) a$ & $0(0-0) a$ \\
\hline
\end{tabular}

Means followed by different letters in the same row indicate statistical at $\mathrm{P}<0.05$.

RBC: red blood cell count; WBC: white blood cell count; PCV: packed cell volume; Hb: hemoglobin concentration; MCV: mean corpuscular volume; MCHC: mean corpuscular hemoglobin concentration; Seg: segmented neutrophils; Band: band neutrophils. * Mean (minimum - maximum). 
It was noted that at 25-months-old, values were lower for $\mathrm{RBC}$ count and $\mathrm{PVC}$ and higher for $\mathrm{MCV}$ in castrated horses (group VI) in comparison with the other groups, regardless of gender. Castrated horses (group VI) were employed in daily work and were maintained on the same nutritional regimen as the other groups, which suggests a possible nutritional deficiency and/or higher energy demand in this group of animals.

According to the findings described in the literature for other breeds, the obtained erythrocyte parameters were lower (Lumsden et al., 1980; Noronha et al., 2000). However, the present data are similar to the values described in sequential studies that showed a broad review of the published works, establishing reference values for hematological parameters for English Thoroughbred, Arabian, and Quarter-horse breeds, among others (Mullen and Hopes, 1979; Rose and Rodgson, 1994; Feldman et al., 2000).

The WBC and segmented neutrophils of foals younger than eight-month-old (Group I) showed higher values than those found in animals older than 25-month-old. WBC diminished as age advanced; however, gender had no influence. Some factors can be postulated as causes of such occurrence, among these, subclinical parasitism. The obtained WBC indexes were higher than those described in the literature for other breeds (Mullen and Hopes, 1979; Lumsden et al., 1980; Rose and Rodgson, 1994; Feldman et al., 2000). However, it should be noted that hematological parameters are influenced by various factors, including the time of sampling, diet, temperament of the horse, and conditioning and physical activities as well (Rose e Rodgson, 1994).

Under the imposed experimental conditions, it was noted that the mean values of the RBC indexes increased with age up to 24 months, and then declined. The values of the $\mathrm{WBC}$ indexes decreased as the animals became older. Gender did not influence on the examined parameters.

Keywords: horses, Pantaneiro breed, hematological profile

\section{RESUMO}

Determinaram-se os valores do hemograma de 187 eqüinos sadios da raça Pantaneira. Para a composição de seis grupos experimentais consideraram-se a faixa etária e o sexo. Verificaram-se 6,2 $\pm 1,2$

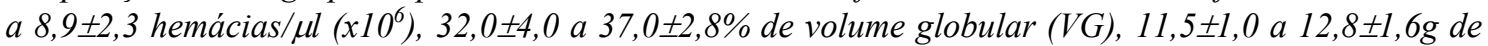

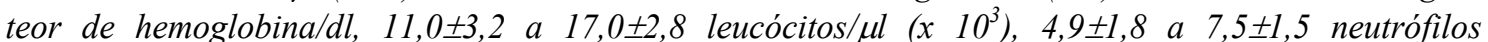

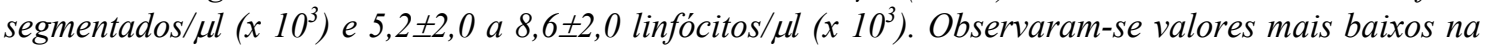
contagem de hemácias, e VG e valores mais altos do volume globular médio (VGM) em cavalos castrados (acima de 25 meses de idade). As contagens de leucócitos e neutrófilos segmentados em potros com até oito meses de idade apresentaram valores mais elevados que os encontrados em animais acima dos 25 meses de idade. Constatou-se que não houve influência do sexo nos parâmetros analisados.

Palavras-chave: eqüino, raça Pantaneira, hemograma

\section{ACKNOWLEDGEMENTS}

The authors express gratitude to the FAPEMAT (Fundação de Amparo à Pesquisa de Mato Grosso) for the financial support, and the ABCCP (Associação Brasileira de Criadores do Cavalo Pantaneiro), and the Hospital Veterinário da Universidade de Cuiabá (UNIC) for technical support.

\section{REFERENCES}

BECK, S.L. Pantaneiro, Nordestino e Marajoara, raças pouco conhecidas. In: Eqüinos: raça, manejo e equitação. São Paulo: Editora dos Criadores, 1985. p.179-190.

COTHRAN, E.G.; SANTOS, S.A.; MAZZA, M.C.M. et al. Genetics of the Pantaneiro horse of the Pantanal region of Brazil. Gen. Mol. Biol., v.21, p.343-349, 1998. 
CUNHA, A.P.; BELLO, A.C.P.P.; LEITE, R.C. et al. Avaliação de parâmetros clínicos e hematológicos de eqüinos submetidos a um programa de controle estratégico de Amblyomma cajennense (Fabricius, 1787) (Acari: Ixodidae). Arq. Bras. Med. Vet. Zootec., v.60, p.113-120, 2008.

FELDMAN, B.F.; ZINKL, J.G.; JAIN, N.C. Schalm's veterinary hematology. 5.ed. Philadelphia: Lippincott Williams \& Wilkins, 2000. 1344p.

LUMSDEN, J.H.; ROWE, R.; MULLEN, K. Hematology and biochemistry reference values for the light horse. Can. J. Comp. Med., v.44, p.32-42, 1980.

MISERANI, M.G.; MCMANUS, C.; SANTOS, S.A. et al. Avaliação dos fatores que influem nas medidas lineares do cavalo Pantaneiro. Rev. Bras. Zootec. v.31, supl., p.335-341, 2002.

MULLEN, P.A.; HOPES, R. The biochemistry, haematology, nutrition and racing perfomance of two-year-old Thorougbreds throughout their training and racing season. Vet. Rec., v.104, p.90-95, 1979.

NORONHA, T.A.; AMARAL, R.C.; FERNANDES, W.R. et al. Influência de fatores etários e sexuais no eritrograma de eqüinos clinicamente sadios, da raça Mangalarga. Rev. Bras. Med. Vet., v.22, p.85-88, 2000.

RIBEIRO C.R.; MARTINS, E.A.N.; RIBAS, J.A.S. et al. Avaliação de constituintes séricos em eqüinos e muares submetidos à prova de resistência de $76 \mathrm{Km}$, no Pantanal do Mato Grosso, Brasil. Cienc. Rural, v.34, p.1081-1086, 2004.

ROSE, R.J.; HODGSON, D.R. Hematology and Biochemistry. In: HODGSON, D.R.; ROSE, R.J. (Eds). The atlhetic horse: principles and practice of equine sports medice. Philadelphia: W.B. Saunders, 1994. p.63-78.

SANTOS, S.A; MAZZA, M.C.M.; SERENO, J.R.B. et al. Avaliação e conservação do cavalo Pantaneiro. Corumbá: Embrapa Pantanal, 1995. 40p. (Circular técnica 21)

SPEIRS, C.V. Clinical examination of horses. Pennsylvania: Saunders, 1997. 358p.

USER'S guide: Statistics. version 8.2. Cary, NC: SAS Institute, 1985. 956p.

TYLER, R.D.; COWELL, R.L.; CLINKENBEARD, K.D. et al. Hematologic values in horses and interpretation of hematologic data. Vet. Clin. N. Am.: Equine Pract., v.3, p.461-484, 1987. 